\title{
Technical Efficiency Analysis of Small Scale Cassava Farmers in Cross River State, Nigeria: A Stochastic Production Frontier Approach
}

\author{
Kingsley Okoi Itam ${ }^{1}$, Eucharia Agom Ajah ${ }^{1}$, Uket Ikpi Ofem ${ }^{1} \&$ Otu Ewa Abam ${ }^{2}$ \\ ${ }^{1}$ Department of Agricultural Economics \& Extension, University of Calabar, Calabar, Nigeria \\ ${ }^{2}$ Department of Economic Empowerment, Niger Delta Development Affairs (NDDA), Abuja, Nigeria \\ Correspondence: Kingsley Okoi Itam, Department of Agricultural Economics \& Extension, University of Calabar, \\ Calabar, Nigeria.
}

Received: May 5, 2015

Accepted: May 20, 2015

Available online: August 10, 2015

doi:10.11114/aef.v2i4.1028

URL: http://dx.doi.org/10.11114/aef.v2i4.1028

\begin{abstract}
The stochastic production frontier was employed in the analysis of the technical efficiency of small scale cassava farmers in Cross River State. A multi-stage random sampling technique was adopted in selecting two hundred (200) cassava farmers from Ikom and Ogoja Agricultural zones in the State. Structured questionnaires were used in collecting data for the study. A stochastic production function, using the Maximum Likelihood Estimating (MLE) technique, was used in estimating the farmer's technical efficiency and their determinants in the study area. The mean technical efficiency of the cassava farmer's was $89 \%$. The result of the generalized Likelihood Ratio (LR) tests confirm that the cassava farmers were technically inefficient, implying that there is room to improve technical efficiency with the farmers' current resource base and available technology. Age and sex of the farmers had negative but significant effect on their technical efficiency, while education, family size, farming experience and farm size had significant and positive influence on farmer's technical efficiency. Therefore, policies that would encourage experienced and educated farmers, especially women to continue in cassava farming are recommended.
\end{abstract}

Keywords: Cassava farmers, technical efficiency, small scale, maximum likelihood, stochastic frontier, determinants.

\section{Introduction}

Agriculture is the major source of livelihood for most developing countries like Nigeria. About $70 \%$ of Nigeria's population are rural dwellers, depending largely on subsistent agriculture for their survival. In spite of this, the agricultural sector has contributed immensely in the development of Nigerian economy; generating employment for about $70 \%$ of the country's population and accounts for about $40 \%$ of the Gross Domestic Product (GDP), with crops accounting for $80 \%$, livestock 13\%, forestry 3\% and fishery 4\% ( Federal Republic of Nigeria, 2006). The crop sub-sector is dominated by food crops such as root and tuber crops production.

In Nigeria, agricultural production is dominated by the small holder farming systems, with farms dominated by small scale farmers who account for about $95 \%$ of total production ( Olujenyo, 2010). This is due to the unattractiveness of agriculture as a result of lack of infrastructures in the rural areas where a bulk of agricultural activities takes place. Also, limited access to credit facilities, modern technology and inefficient use of resources have been the bane of small scale agriculture in Nigeria.

Cassava is one of the major root crops cultivated in Cross River State, and in Nigeria as a whole. Nigeria is adjudged the largest producer of cassava in the world with a substantial output estimated at about 34 million tonnes ( Food and Agriculture Organization, 2004a), while the Central Bank of Nigeria (2006), reported an estimated annual production of 49 million tonnes. This is far more than production in other African countries. Cassava is a very versatile commodity with numerous uses and by products. Every component of the plant is valuable to its cultivator. The leaves may be consumed as a vegetable, or cooked as a soup ingredient or dried and fed to livestock as a protein feed supplement. The stem is used for plant propagation and grafting, while the roots are processed for human and industrial consumption. Cassava not only serves as food crop, it is a major source of income and employment for rural dwellers in Nigeria. It constitutes a major food crop for most urban and rural communities in Nigeria ( Abang et al, 2001). However, production is still in small scale and this account for low productivity and poor returns on investment. 
Therefore, in view of the various government agricultural programmes and policies put in place to raise farmer's productivity, it is imperative to empirically determine farmer's current levels of technical efficiency and their determinants with a view to suggesting relevant policy options to adopt, in order to raise their efficiency. This is because there is a direct relationship between efficiency of production and the overall productivity of the agricultural sector. For Nigeria, raising productivity per area of land is the key to effectively address the challenges of achieving food security as most cultivable, physical and technological constraints prevent large-scale conversion of potentially cultivable land ( Ajibefun, 2002).

The importance of cassava as a staple food crop in addressing the food security challenges of Nigeria cannot be over-emphasized because of the socio-economic potentials of crop. The Federal Government of Nigeria did set up a Presidential Initiative on cassava production and export in 2002, with the aim of diversifying and expanding the uses of cassava and create opportunities for income generation for the rural populace. In 2004, President Olusegun Obasanjo introduced a policy to incorporate $10 \%$ cassava in bread production in Nigeria. In view of this development, the role of increased efficiency vis-a-vis productivity of cassava farm is no longer debatable. Studies have shown that, cassava farmers in Cross River State in particular, and Nigeria generally are inefficient in resource use and therefore experience low productivity (Edimetta,1987; Enun, 1990; Abang et al, 2001; Aji, 2004; Abang and Agom, 2004).

Therefore, this study is to analyze the technical efficiency of cassava farmers in Ikom and Ogoja Agricultural zones of Cross River State, with a view to determine the technical efficiency of the farmers, ascertain the factors that influence the technical efficiencies as well as derive policy implications and make recommendations based on the findings of the study.

The null hypotheses are stated as follows ;

$\mathrm{H}_{\mathrm{Oi}}$ : There is no significant relationship between farm size, labour, capital and cassava cuttings,and farmer's output of cassava.

$\mathrm{H}_{\mathrm{ai}}$ : There is significant relationship between farm size, labour, capital and cassava cuttings, and farmer's output of cassava.

$\mathrm{H}_{\text {Oii }}$ : The cassava farmers are fully technically efficient.

$\mathrm{H}_{\mathrm{aii}}$ : The cassava farmers are not fully technically efficient.

\section{Theoretical Framework and Literature Review}

The production and efficiency theories are of relevance to this study. The production theory basically involves the process of choice among several alternatives in the production of a given good and the firm is the centre of economic activities. Olayide and Heady (1982), and Ojo (2004), defined production process as one whereby some goods and services called inputs are transformed into other goods and services called output. Koutsoyiannis (1979), refers to this technical relationship as the production function and involves the use of input(s). In agriculture, major inputs will include land, capital, labour and management of resources ( Abang et al, 2008).

The production function is purely a technical relationship which connect factor inputs and outputs. It describes the laws of proportion, that is the transformation of factor inputs into products ( output), at any particular time period. Abang et al (2008), defined production function as purely technical relationship between quantities of various input used and the optimum output of the commodity that is produced. Emphasizing further, that it basically gives a summary of the technical efficient methods of combining resources to produce an output. Production function exhibit the law of diminishing returns (Foster and Ervan, 1981). The law states that, if additional units of an input is held constant, output increases at a decreasing rate reaches a maximum and finally declines. Therefore, it is best to produce at the point where additional use of input increases output at increasing rate, considered to be the rational stage, and cease further addition of input where output begin to decline.

The concept of efficiency is viewed by different authors in different light. In all these, they tend to agree that efficiency involves minimizing input use to maximize output. Farell ( 1957) asserted that, the efficiency that is associated with physical economies of scale are characterized as technical efficiency, and is defined as the measure of the firm's success in producing maximum output from a given set of inputs. The best production process is one that uses the fewest inputs or the one that is technically most efficient, (Lipsey and Steiner, 1981). An increase in production will arise either by using the same amount of resources to produce greater output or a reduction of the resource to produce the same level of output. Abang et al (2001), and Olayide and Heady (1982), maintained that productivity and efficiency measures are synonymous. They stated that, there is an obvious relationship between optimal productivity and efficient resource utilization and affirmed that when efficiency is defined in terms of marginal productivity, farmers would employ factors up to the point where the marginal productivity of resources are equal to the ratios of their prices and marginal factor cost in competitive resources and output markets. Farell (1957), divided efficiency into technical, allocative and 
economic efficiency. Technical efficiency measures the maximum equiproportion reduction in all inputs and still allows continued production of given outputs. The technical inefficiency measures the magnitude. The allocative efficiency reflects the ability of a firm to use the inputs in optimal proportions, given their respective price. These two concepts form the concept of economic efficiency (Coelli, 1995).

The level of technical efficiency of a particular farmer is characterized by the relationship between observed production and some ideal or potential production (Greene, 1980). The measurement of firm specific technical efficiency is based upon deviations of observed output from the best production or efficient production frontier. If a farmer's actual production point lies on the frontier it is perfectly efficient. If it lies below the frontier then it is technically inefficient, with the ratio of the actual to the potential production defining the level of efficiency of the individual farmer (Ogundele and Okoruwa, 2006).

Empirical evidence have shown that production variables such as farm size, labour, fertilizer, seedlings, use of chemicals, and socio-economic characteristics like age, family size, education, gender, experience have influence on technical efficiency. Iheke (2008), in the study of technical efficiency of cassava farmers in South Eastern Nigeria, found that education, farmer's experience, membership of farmer's association, credit, household size, improved cassava variety and farm size were significantly related to technical efficiency, while age and extension contact were not. They recorded a technical efficiency range of $52-95 \%$ and a mean of $77 \%$.

Rahman and Umar (2009), in their study of measurement of technical efficiency and its determinants in crop production, found that technical efficiency was affected by age, gender, marital status, household size, other occupation and land ownership. The study further revealed that farm size and fertilizer were the major inputs that determined output in the study area. A mean efficiency of $69.6 \%$, and a range of $32.7-89.4 \%$ was observed.

Onoja, Ibrahim and Achike (2009), in econometric analysis of credit and farm resource technical efficiencies' determinants in cassava farms, also observed that farm credit, farm size, chemical, fertilizer quantity, labour and seedlings were significant determinants of technical efficiency in the study area. The study revealed efficiency range of $62-99 \%$ and a mean of $81 \%$, far more than that of Iheke, and Rahman and Umar.

Orewa and Izekor (2012), in their study of technical efficiency analysis of yam production, observed that educational level, household size and farming experience

had negative influence on farmer's technical efficiency, while farm size, yam sett, fertilizer and labour were statistically significant and positively related to farmers' output. Also, a mean technical efficiency of $69.32 \%$ and a range of $0.001-96.50 \%$ were observed.

Similarly, Adewuyi, Agbonahor and Oke (2013), in technical efficiency analysis of cassava farmers, revealed that farm size, agrochemicals, labour (hired and family)

and quantity of fertilizer significantly affected cassava production. Farmers efficiency range were $40-96 \%$ and a mean of $68 \%$. The study concluded that farmers were efficient in resource use in the study area.

In another study carried out by Ogunniyi, Ajetombi and Fabiyi (2013), on technical efficiency of cassava-based cropping systems, farm size and cassava cuttings were found to be the significant determinants of production, with a mean technical efficiency of 0.542. Unlike Adewuyi et al, the study concluded that farmers were inefficient in resource use since they were not operating on the production frontier. In all the studies, the use of stochastic production frontier approach was employed in the determination of efficiency, but the authors failed to show whether the farmers were technically efficient or inefficient, except for Adewuyi et al and Ogunniyi et al.

\section{Research Methodology}

\subsection{Study Area}

Cross River State is located in the South-South geopolitical zone of Nigeria. It lies within latitude $40^{\circ} 4$ ", South and $60^{\circ}$ 30 ", North and between longitude $8^{0}$ and $9^{0} 00^{\prime \prime}$ East of the equator. The State is bounded in the North by Benue State, by the Atlantic Ocean in the south and in the East and West, by Cameroun Republic and Akwa Ibom, Abia and Ebonyi States respectively. There are three distinct ecological zones found in the State, these are the mangrove forest in the south, and the tropical rain forest and guinea savanna in the middle and north respectively, with an annual rainfall ranges between $1500 \mathrm{~mm}-2000 \mathrm{~mm}$.

The area supports the production of tree crops like cocoa, rubber, cashew, palm oil and food crops such as cassava, maize, yam, cocoyam etc. The people of Cross River State are predominantly peasant farmers with small farm holdings. The area is well known for rain-fed agriculture with mixed cropping as the most common farming system.

\subsection{Sampling procedure and Sample Size}

The study adopted the multistage random sampling technique. The first stage involved the purposive random selection 
of four (4) Local Government Areas ( Two each in Ikom and Ogoja Agricultural zones). Etung and Boki Local Government Areas were selected from Ikom zone, while Yala and Ogoja were selected from Ogoja zone. In the second stage, five (5) villages were randomly selected from the four (4) Local Government Areas, giving a total of twenty (20). Then a proportionate random sample of two hundred (200) farmers were selected for the study. Structured questionnaires were used to collect data and information on cassava output per farmer, farm size, labour, quantity of cassava cuttings used and farmers' socio-economic characteristics were obtained for the 2014 production season.

\subsection{Analytical Method}

The econometric model was employed in analyzing the data for this study. Specifically, data were analyzed using the stochastic production frontier approach to determine as well as ascertain the factors that influence technical efficiency of cassava farmers in the study area. Also, a generalized Maximum Likelihood test was carried out to test the hypothesis of full technical efficiency. It is stated as;

$$
\text { LR }=-2 \mathrm{In}\left(\log \mathrm{H}_{1}-\log \mathrm{H}_{2}\right)
$$

$\mathrm{H}_{2}$ is the log-likelihood function of the frontier function. The value has a mixed Chi square $\left(\mathrm{X}^{2}\right)$ distribution with degrees of freedom equal to the number of parameters plus one.

\subsection{Model Specification}

The stochastic production frontier function allows for the simultaneous estimation of individual technical efficiency of the respondent farmers as well as determinants of technical efficiency ( Battese and Coelli, 1995). It is expressed as follows;

Where;

$$
\mathrm{Y}=\mathrm{f}\left(\mathrm{X}_{\mathrm{i}} ; \beta\right) \exp \left(\mathrm{V}_{\mathrm{i}}-\mathrm{U}_{\mathrm{i}}\right), \mathrm{I}=1,2,3 \ldots, \ldots \mathrm{N} \ldots \ldots \ldots
$$

$\mathrm{Y}:$ is the output ith enterprise (farm)

$\mathrm{X}$ : is the vector input quantities used by the ith enterprise

$\beta$ is a vector of unknown parameters to be estimated

$\mathrm{f}($ ): represents an appropriate function ( e.g Cobb-Douglas, Translog, etc.)

$\mathrm{V}_{\mathrm{i}}$ : is a symmetric error, which accounts for random variation in output due to factors such as weather, disease outbreak, measurement errors etc, which are beyond the farmer's control.

$\mathrm{U}_{\mathrm{i}}$ is a non-negative random variable representing inefficiency in production relative to the stochastic frontier, that is a one sided error component.

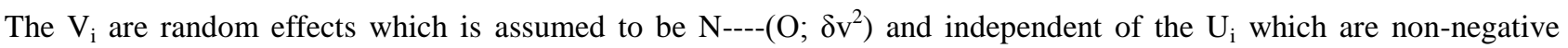
truncation of the N-----(O; $\left.\delta u^{2}\right)$ distribution ( i.e half-normal distribution or exponential or gamma distributions). The technical efficiency of an individual enterprise is defined in terms of the ratio of the observed output to the corresponding frontier output, given the available technology.

$$
\text { Technical efficiency }(T E)=Y^{*} / Y_{i}=f\left(X_{i} \beta\right) \exp \left(V_{i}-U_{i}\right) / f\left(X_{i} \beta\right) \exp \left(V_{i}\right) \exp \left(-U_{i}\right)
$$

Where;

$\mathrm{Y}$ : is the observed output and $\mathrm{Y}^{*}$ is the frontier output. The parameters of the stochastic frontier production function are estimated using the Maximum Likelihood Estimation (MLE) method.

The specified cassava production function is given as follows;

$$
\operatorname{LnY}=\beta_{0}+\beta_{1} \operatorname{Ln} X_{1}+\beta_{2} \operatorname{LnX} X_{2}+\beta_{3} \operatorname{Ln} X_{3}+\beta_{4} \operatorname{LnX} X_{4}+\varepsilon_{i}
$$

Where;

Ln represents the natural logarithm

$\mathrm{Y}=$ Output of Cassava in kilograms $(\mathrm{kg})$

$\mathrm{X}_{1}=$ Farm size $($ ha $)$

$\mathrm{X}_{2}=$ Labour ( man-days)

$\mathrm{X}_{3}=$ Capital

$\mathrm{X}_{4}=$ Cassava cuttings

$\beta_{0}=$ Intercept

$\varepsilon_{\mathrm{i}}=$ Random error 
$\beta_{0}$ to $\beta_{4}$ are coefficients to be estimated.

Some socio-economic factors were incorporated directly into the frontier model in order to determine their influence on farmer's technical efficiency. The technical efficiency model is specified as:

$$
\mathrm{TE}=\alpha_{0}+\alpha_{1} \mathrm{Z}_{1}+\alpha_{2} \mathrm{Z}_{2}+\alpha_{3} \mathrm{Z}_{3}+\alpha_{4} \mathrm{Z}_{4}+\alpha_{5} \mathrm{Z}_{5}+\alpha_{6} \mathrm{Z}_{6}+\varepsilon
$$

Where;

$\mathrm{TE}=$ Technical efficiency of the ith farmer

$\mathrm{Z}_{1}=$ Age of farmer (years)

$\mathrm{Z}_{2}=$ Experience (years)

$\mathrm{Z}_{3}=$ Educational level (years of schooling)

$\mathrm{Z}_{4}=$ Farm size (ha)

$\mathrm{Z}_{5}=$ Family size

$\mathrm{Z}_{6}=$ Farmer's sex (dummy)

$\alpha_{0}$ is the intercept, $\alpha_{0}$ to $\alpha_{6}$ are coefficients to be estimated.

\section{Results and Discussion}

\subsection{Mean output and other production variables in cassava production in Cross River State}

The statistics of the production variables shows that mean output of cassava per farmer in the area is $1,309 \mathrm{~kg}$, and mean yield per farmer is about $422 \mathrm{~kg}$ per hectare ( table 1). This is lower than the recommended national average of 35000 to $45000 \mathrm{~kg}$ per hectare. The mean man-days for labour is about 160.71 , indicating that cassava production is labour intensive, which is common in small scale agriculture owing to the non- mechanization of the production process (Idiong, 2006). The mean farm size of $0.31 \mathrm{ha}$ is an indication of the preponderance of small size cassava farms in Cross River State. This result corroborates the findings of Itam et al (2014), and Abang and Agom (2004), who reported 0.98 and 0.05 ha respectively. On the average, the cassava farmers planted about 13 bundles of cassava cuttings on their farms, and quantity per hectare of about 45 bundles, which is slightly lower than the recommended 50 bundles.

Table 1. Summary statistics of output and input variables in cassava production in Cross River State

\begin{tabular}{lccc}
\hline Variables & Unit & Mean & Standard error \\
\hline Output $(\mathrm{Y})$ & $\mathrm{Kg}$ & 1309.71 & 56 \\
Farm size $\left(\mathrm{X}_{1}\right)$ & Hectares & 0.31 & 0.017 \\
Labour $\left(\mathrm{X}_{2}\right)$ & Man-days & 160.71 & 4.47 \\
Capital $\left(\mathrm{X}_{3}\right)$ & Naira & 2639.18 & 113.85 \\
Cassava Cuttings $\left(\mathrm{X}_{4}\right)$ & Bundles & 13 & 2.55 \\
\hline
\end{tabular}

Source: Derived from field survey data 2013/ 2014

4.2 Maximum likelihood estimates of stochastic production frontier function for cassava farmers in Cross River State

The Maximum Likelihood Estimates of the Cobb-Douglass stochastic production frontier function for cassava farmers in the study area is presented in Table 2 . The variance parameters are represented by sigma squared $\left(\delta^{2}=0.62\right)$ and gamma $(\gamma=0.99)$. The value of the sigma square $\left(\delta^{2}\right)$ is large enough at 0.62 and significantly different from zero at $5 \%$ level. This indicates goodness of fit as well as correctness of the distributional form assumed for the composite error term. Also, the high value of gamma $(\gamma)=0.99$ indicates that the influences that were unexplained by the production function are the main sources of random error. It is significant at one percent level and indicates that $99 \%$ of the variation in farmer's output is a consequence of technical inefficiency in the study area. Thus, the presence of one-sided error component in the model is confirmed and the average production function (Ordinary Least Square, OLS) is inadequate in representing the data.

Furthermore, the estimated coefficients of the stochastic production frontier are positive, implying that a positive relationship exists between farmer's output of cassava, and farm size, labour, cassava cuttings and capital respectively. This is so, because these inputs are important determinants in agricultural production. The positive signs of the 
coefficients, implies that increasing any of farm size, labour, cassava cuttings and capital will results to increase output of cassava in the study area. Therefore, the null hypothesis of there is no significant relationship between farm size, labour, capital and cassava cuttings, and farmer's output of cassava is rejected.

Table 2. Maximum likelihood estimates of the stochastic production frontier function for cassava farmers

\begin{tabular}{lccc}
\hline Variables & Coefficients & Standard Error & t-ratio \\
\hline Intercept & 3.212 & 0.3094 & $10.37^{* * *}$ \\
Farm size $\left(\mathrm{X}_{1}\right)$ & 0.4756 & 0.1019 & $4.66^{* * *}$ \\
Labour $\left(\mathrm{X}_{2}\right)$ & 0.3989 & 0.0987 & $4.44^{* * *}$ \\
Capital $\left(\mathrm{X}_{3}\right)$ & 0.0429 & 0.0097 & $0.04^{* * * *}$ \\
Cassava Cuttings $\left(\mathrm{X}_{4}\right)$ & 0.1946 & 0.0864 & $2.25^{* * *}$ \\
Diagnostic statistics & & & \\
Gamma $(\gamma)$ & 0.9999 & 0.085 & $11.68^{* * * *}$ \\
Sigma square $\left(\delta^{2}\right)$ & 0.62 & 0.085 & $2.0^{* * *}$ \\
Log Likelihood Function & 61.72 & & \\
LR test & 28.13 & & \\
\hline
\end{tabular}

Source: Computed from field survey Data 2013/2014.

$* * *$ Significant at $1 \%, * *$ Significant at $5 \%$.

\subsection{Technical efficiency estimates of the Sampled Cassava Farmers}

The result of the technical efficiency estimates of the cassava farmers shows that efficiencies range from 61 to $99 \%$ and a mean technical efficiency of about $89 \%$ ( Table 3). This is higher than $77 \%, 70 \%$ and $68 \%$ obtained by Iheke(2008), Rahman and Umar

(2009) and Adewuyi et al (2013) respectively, for cassava farmers in their studies. The efficiency distribution indicates that, majority (34\%) of the farmers were in the modal class of above $90 \%$, while $17.25 \%$ were within the $61-70 \%$ levels of technical efficiency. The relatively high levels of efficiency of the cassava farmers suggests that only a small fraction of the output can be attributed to resource wastage.

Table 3. Distribution of technical efficiency of cassava farmers in Cross River State

\begin{tabular}{lcc}
\hline Efficiency Class & No of Farmers & Percentage \\
\hline $61-70$ & 35 & 17.50 \\
$71-80$ & 45 & 22.50 \\
$81-90$ & 52 & 26.00 \\
$>91$ & 68 & 34.00 \\
Total & 200 & 100 \\
Mean & 89 & \\
Standard Deviation & 6.65 & \\
Minimum & 61 & \\
Maximum & 99 & \\
\hline
\end{tabular}

Source: Derived from output of computer programme

\subsection{Determinants of Technical Efficiency of Cassava Farmers}

Farmer's socio-economic factors can influence his ability to make use of the available technology and as such not operate on the efficiency frontier. Based on this, some socio-economic variables were included in the model to determine their influence on the farmer's technical efficiency. The signs of the estimated coefficients in the model have important implications on the technical efficiency of cassava farmers in the study area. The result shows that the coefficients of farmer's experience, education and family size were positive and significant at the $5 \%$ level (Table 4). This implies that experienced farmers obtained higher levels of technical efficiency. This is because farmers usually 
count on experience and are more likely to accept innovations than inexperienced farmers. The positive and significant coefficient sign of education also implies that the cassava farmer's level of technical efficiency increases with his level of education. This is expected, because an educated farmer has the capacity to understand and adopt improved technology that would shift his production frontier upwards. Also, since family size returned positive and significant sign, it follows that increase in family size would result in increased levels of technical efficiency of the cassava farmers. Cassava farming requires a lot of farm hand and given the fact that farming is still at the subsistent level in the study area, increases in family sizes would make labour readily available and reduce high cost of hired labour. This result corroborates that of Iheke (2008), but disagree with that of Orewa and Izekor (2012), whose results had negative coefficients but significant.

On the other hand, the coefficients of age and sex of the farmers were negative and are significant at the $1 \%$ level. The negative and significant relationship between the farmers age and technical efficiency level implies that older farmers are less efficient compared to the younger ones. It further implies that the older farmers will be less willing to adopt improved technology due to their conservative attitudes, hence their low levels of technical efficiency. However, the result varies with that of Kebede (2001), who reported a positive coefficient for age. The negative and significant coefficient sign of sex is an indication that women cassava farmers obtained higher levels of technical efficiency than their male counterparts in the study area.

Table 4. Maximum likelihood estimates of determinants of technical efficiency of cassava farmers in Cross River State

\begin{tabular}{llll}
\hline Variables & Coefficients & Standard errors & t-ratios \\
\hline Intercept & -0.2613 & 0.7678 & -0.340 \\
Age $\left(\mathrm{Z}_{1}\right)$ & -0.1359 & 0.0534 & $-0.54 *^{* *}$ \\
Farming Exp. $\left(\mathrm{Z}_{2}\right)$ & 0.6575 & 0.2467 & $2.67 * *$ \\
Educational level $\left(\mathrm{Z}_{3}\right)$ & 0.1436 & 0.0625 & $2.29 * *$ \\
Farm size $\left(\mathrm{Z}_{4}\right)$ & 0.0734 & 0.1059 & 0.5494 \\
Family size $\left(\mathrm{Z}_{5}\right)$ & 0.5821 & 0.0349 & $2.333^{* *}$ \\
Sex $\left(\mathrm{Z}_{6}\right)$ & -0.2333 & 0.0876 & $2.663^{* *}$ \\
\hline
\end{tabular}

Note : ** Significant at $5 \%$ level

Source: Computed from Field Survey data 2013/2014

Further analysis shows that the cassava farmers were not fully technically efficient in the study area. This is revealed in a test of hypothesis for full technical efficiency using the generalized likelihood ratio test, as shown in table 5. Again, the null hypothesis of full technical efficiency was rejected.

Table 5. Test of hypothesis that cassava farmers in Cross River State are fully technically efficient $\left(\mathrm{H}_{\mathrm{oii}}=0\right)$

\begin{tabular}{lllll}
\hline Efficiency & $\begin{array}{l}\text { Likelihood } \\
\text { function }(\kappa)\end{array}$ & $\begin{array}{l}\text { Log likelihood } \\
\text { Ratio(LR) }\end{array}$ & Critical $\chi^{2} 0.05$ & Conclusion \\
\hline Technical & 61.72 & 28.13 & 11.91 & Reject \\
\hline
\end{tabular}

Source: Derived from data analysis 2013/2014. Critical $\chi^{2}$ values were obtained from Kodde and Palm (1986)

\subsection{Elasticity of Cassava Production and Returns to Scale}

The estimated coefficients for the specified function are explained as the elasticities of the explanatory variables. The analysis shows that a 10\% increase in farm size, labour, capital and cassava cuttings will lead to a 4.7, 3.9, 0.4 and 1.9\% increase respectively in cassava output (Table 6). The value of the returns to scale (RTS=1.112) shows that the farmers were producing at the economic region of increasing returns ( Stage II). This implies that increasing the units of inputs will lead to further increases in cassava output towards the frontier.

Table 6. Elasticity of cassava production and returns to scale

\begin{tabular}{ll}
\hline Variables & Elasticity \\
\hline Farm size & 0.4756 \\
Labour & 0.3989 \\
Capital & 0.0429 \\
Cassava Cuttings & 0.1946 \\
RTS & 1.112 \\
\hline
\end{tabular}

Source : Field data ,2013/2014 


\section{Conclusion}

The study shows that cassava farmers in the study area are not fully technically efficient in their resource use. This is due to their allocative inefficiency. Therefore, there is need to determine and improve the levels of allocative efficiency of the farmers so that the overall efficiency (economic efficiency) can be substantially improved with the farmers' current resources base and technology. The variables that were identified as having significant effects on technical efficiency levels of the farmers were age, education, farming experience, family size and sex.

Therefore, the following policy options are suggested in order to address the technical inefficiency in resource use of the cassava farmers;

Government should strengthen its policy on the provision of incentives such as access to affordable inputs including credit and land. This would make cassava farming attractive to younger and middle aged persons, and possibly older ones to continue in cassava production most importantly in the short run.

Since education is an important variable that influenced technical efficiency, farmers should be encouraged to acquire formal education to at least the primary level. This could be achieved by strengthening the capacity of the available Adult and Continuing education centers in the area.

The importance of family labour in cassava farming cannot be overemphasized. However, the small scale nature of cassava farming in the area results in it over utilization, and therefore a major problem in increasing productivity. Therefore, programmes that would results in the creation of off farm job opportunities should be formulated and implemented. This will go a long way in addressing the problem of family labour saturation inherent in small scale agriculture especially in the short run.

It is also imperative that policies that would encourage experienced farmers to remain in cassava farming are advocated. The fact that women cassava farmers were more efficient than their male counterparts in the study area calls for gender mainstreaming, when policies that would cause improvement in efficiency are made for implementation.

\section{References}

Abang, S. O., \& Agom, D. I. (2004). Resource use efficiency of small holder farmers: The case of cassava producers in Cross River State, Nigeria. Journal of Food, Agriculture and Environment, 2(3\&4), 87-90

Abang, S. O., Agom, D. I., \& Enyenihi, E. A., \& Ele, I. E. (2008): Introduction to farm management, (principles, plans, budgets and control). Calabar: King Judah Publishers, Cross River State, Nigeria.

Abang, S. O, Ekpe, E. E., \& Usani, W. W. (2001). Technical and Allocative Efficiencies of small scale cassava growers in five selected local government areas of Cross River State, Global Journal of pure and Applied Science, 3(1), $37-42$

Adewuyi, S. A., Agbonlahor, M. U., \& Oke, A. T. (2013). Technical Efficiency Analysis of cassava farmers in Ogun State, Nigeria. International Journal of Agriculture and Food Science, 4(1\&2), 515-522.

Aji, M. J. (2004). Estimating Allocative Efficiency of small holder managed cassava Enterprises in Itigid, Abi Local Government Area of Cross River State". Unpublished MSc Thesis, Department of Agricultural Economics and Extension, University of Calabar, Nigeria.

Ajibefun, I. A. (2002). Analysis of Policy Issues in Technical Efficiency of small scale farmers using the Stochastic Frontier Production Function with application to Nigerian Farmers. A paper presentation at the International Farm Management Association Conference. Wageningen, Netherland.

Battese, G. E, \& Coelli, T. (1995). A model of technical inefficiency effects in a stochastic frontier production function for panel data. Empirical Economics, 20, 325-332.

Central Bank of Nigeria. (2006). Annual report and statement of accounts. CBN Publication Abuja, Nigeria.

Coelli, T. J. (1994). A Guide to Frontier 4.1: A computer programme for stochastic frontier production and cost function estimation. Department of Economics, University of New England, Armidale.

Coelli, T.J.(1995): Recent Developments in Frontier Modeling and Efficiency Measurement, Australian Journal of Agricultural Economics, 39(3), 219-245.

Edimetta, B. (1987). Economics of cassava production in Calabar. Unpublished BSc Thesis. Department of Agricultural Economics and Extension, University of Calabar, Calabar, Cross River State, Nigeria.

Enun, E. E. (1990). An Economic study of cassava production by women in Biakpan of Biase Local Government Area, Cross River State. Unpublished Msc Thesis, University of Calabar, Calabar, Cross River State, Nigeria.

FAO. (2004a). Food and Agriculture Organization Statistical Year Book. A Publication of FAO, Rome. 
Farell, J. M. (1957).The measurement of productive efficiency. Journal of Royal Statistical Society ( Series A: General) 120(111), 253-290.

FGN (2006). Federal Government of Nigeria, Statistics year book, 5.

Forster, D. L., \& Ervan, B. L. (1981).Foundations for Managing the Farm Business. Columbus: Grid Publishing Incorporated, Ohio.

Greene, W. H. (1980). Maximum likelihood estimation of econometric frontier functions. J.Econ.13(1), 27-56, http://dx.doi.org/10.1016/0304-4076(80)90041-x

Idiong, I. C. (2006). Evaluation of technical, allocative and economic efficiencies in rice production systems in Cross River State, Nigeria, Unpublished Ph.D Thesis, Department of Agricultural Economics, Micheal Okpara University of Agriculture, Umudike, Abia State, Nigeria.

Iheke, O. R. (2008).Technical Efficiency of Cassava Farmers in South Eastern Nigeria: Stochastic Frontier Approach. Agricultural journal, 3(2), 152-156.

Itam, K. O., Ajah, E. A., \& Agbachom, E. E. (2014).Analysis of Determinants of Cassava Production and Profitability in Akpabuyo Local Government Area of Cross River State, Nigeria. International Business Research, 7(12).128-135. http://dx.doi.org/10.5539/ibr.v7n12p

Kebede, T. A. (2001).Farm household technical efficiency: A stochastic frontier analysis; a study of rice producers in mardi-watershed in the Western Development Region of Nepal. M.Sc Thesis, Department of Economics and Social Science, Agricultural University of Norway.

Kodde, F. C., \& Palm, D. C. (1986).Wald Criteria for jointly testing equality and in equality restrictions. Econometrica 54, 1243-1248. http://dx.doi.org/10.2307/1912331

Koutsoyainnis, A. (1979). Theory of Economics, Second edition(ed): London: Macmillian Press Limited.

Lipsey, R. G., \& Steiner, P. O. (1981).Economics: Sixth edition. New York: Harper and Row Publishers.

Ogundele, K. \& Ojo, S. O. (2006).An examination of technical, economic and allocative efficiency of small farms: The case study of cassava farmers in Osun State of Nigeria. Journal of Central European Agriculture, 7(3), 423-432.

Ogunniyi, L. T., Ajetomobi, J. O., \& Fabiyi, Y. L. (2013).Technical Efficiency of Cassava-Based Cropping in Oyo State of Nigeria. AGRIS on-line Papers in Economics and Informatics, 5(1).

Ojo, S. O. (2004).Improving labour productivity and technical efficiency in food crop production: A panacea for poverty reduction in Nigeria. Journal of Food, Agriculture and Environment, 2(2), 227-232.

Olayide, S. O. \& Heady, E. O. (1982).Introduction to Agricultural Production Economics. Ibadan University Press: Nigeria.

Olujenyo, F. O. (Ed.).The Determinants of Agricultural Production and Profitability in Akoko Land, Ondo State, Nigeria. http://dx.doi.org/10.3844/jssp.2008.37.41

Onoja, A. O., Ibrahim, M. K., \& Achike, A. I. (2009).Econometric Analysis of Credit and Farm Resource Technical Efficiencies' Determinants in Cassava Farms in Kogi State, Nigeria: A Diagnostic and Stochastic Frontier Approach. www. africametrics. Org/documents/conference09/papers. Retrieved on April $22^{\text {nd }} 2015$ at $11.03 \mathrm{am}$.

Orewa, S. I., \& Izekor, O. B. (2012).Technical efficiency analysis of yam production in Edo State: A Stochastic frontier approach. International Journal of Development and Sustainability, 1(2), 516-526

Raghman, S. A., \& Umar, H. S. (2009).Measurement of Technical Efficiency and its determinants in Crop production in Lafia Local Government Area of Nasarawa State, Nigeria. Journal of Agriculture, Food, Environment and Extension, 8(2), 90-96.

\section{(c) EY}

This work is licensed under a Creative Commons Attribution 3.0 License. 